\title{
The Cause for Heart Disease and Strokes
}

\author{
Fred A. Kummerow ${ }^{*}$
}

Department of Comparative Biosciences, University of Illinois at Urbana-Champaign, 1208 W Pennsylvania Ave. Urbana, IL 61801, USA

\begin{abstract}
There has been no solution to heart disease to date. I obtained discarded veins from bypass (CABG) surgeries and subjected them to phospholipid analysis. We also obtained arterial cells from human umbilical cords and cultured them with a decreasing concentration of either cholesterol or oxidized cholesterol. Patients undergoing CABG surgery and aging swine had significantly higher levels of sphingomyelin in their arterial cells than arterial cells from human umbilical cords. Oxidized low-density lipoprotein (OxLDL) and oxysterols further contribute to atherosclerosis by increasing the synthesis of thromboxane in platelets, a clotting factor. When we incubated arterial cells with cholesterol that had not been oxidized, even at twelve times the concentration of the oxidized cholesterols we used, there was no effect on sphingomyelin content, this shows that cholesterol itself is not the reason for heart disease, and has to be oxidized in order to cause harm. My study indicated that atherosclerosis is due to a diet that contains a high level of oxysterols. Normal levels of oxysterols in the plasma will not increase sphingomyelin levels. Removing oxidized fat from the diet should be considered as a therapeutic measure for atherosclerosis. Ancel Keys, who some consider the father of the cholesterol-heart disease hypothesis said in 1997: "There's no connection whatsoever between the cholesterol in food and cholesterol in the blood."
\end{abstract}

Keywords: Oxysterols, phospholipids, cholesterol, calcium, oxidation.

Staprans et al. [1] fed rabbits a chow diet to a control group, which received cholesterol that had been stored at $70^{\circ} \mathrm{C}$ under $\mathrm{N}_{2}$ to prevent oxidation. A second group received the same diet plus $25 \mathrm{mg}$ oxidized cholesterol per day. Five oxysterols were found in the plasma of these rabbits. Staprans, et al. demonstrated that oxidized cholesterol in the serum of rabbits is both synthesized endogenously and derived from food. DeBakey et al. [2] had noted thickening at branching and bifurcations during CABG surgery. Thickening was also noted in the branching arteries in aging swine on a cholesterol-free diet [3]. It did not differ significantly in sphingomyelin composition from that of the nonbranching adjacent tissue of pigs at 6 months of age. By 18 and 48 months of age, however, the sphingomyelin content was significantly higher at the thickened branching areas than at the non-thickened segment of the arteries. This indicated that during aging of the arteries, there was a striking increase in the amount of sphingomyelin in the branching points. Lipids extracted from both swine and human arteries indicated that aging is a factor that increases sphingomyelin. The non-branching segment of the aorta, obtained on autopsy from six men 21-27 years of age, contained four times more sphingomyelin than arteries isolated from human placenta, indicating that the sphingomyelin content of arteries increases with age. Aging is not the only factor that increased the sphingomyelin composition of arterial cells. Women

\footnotetext{
*Address correspondence to this author at the Department of Comparative Biosciences, University of Illinois at Urbana-Champaign, 1208 W Pennsylvania Ave. Urbana, IL 61801, USA; Tel: 217-344-6380;

E-mail: fkummero@illinois.edu
}

and men under 40 years of age who had been subjected to CABG surgery contained the same high percentage of sphingomyelin in their non-atheromatous arterial cells as those over 40 years of age. A premature increase in sphingomyelin in nonatheromatous arterial cells in CABG patients pointed to a fundamental disturbance in phospholipid metabolism in their arterial cells.

With permission of the University of Illinois and the Carle Foundation Institutional Review Boards, I obtained arteries from human umbilical cords and discarded veins from CABG surgeries from Carle Hospital. Cholesterol increases the concentration of sphingomyelin and decreases the amount of phosphatidylcholine. Patients who had $10.0 \%$ more sphingomyelin than the CABG patients also had plaques in their arteries.

In an article by Zhou, Smith, and Kummerow [4], it was found that exposure of human smooth muscle cells to $0.5 \%$ ethanol had no cytotoxic effect, as was shown previously with animal smooth muscle cells. Cholesterol, up to $10 \mu \mathrm{g} / \mathrm{ml}$, did not alter cell growth over 5 days of treatment. In contrast, however, oxysterols at a concentration of $2.5 \mu \mathrm{g} / \mathrm{ml}$ caused a decrease in the cell number, cell viability, and DNA and protein content within 2 days of exposure. Reducing the oxysterol concentration to $0.5 \mu \mathrm{g} / \mathrm{ml}$ still resulted in a significant decrease in the cell number in 3 days of treatment. Most remarkably, when arterial cells were incubated with non-oxidized cholesterol, even at twelve times the concentration of the oxidized cholesterols we used, there was no effect on sphingomyelin content. 
This shows cholesterol is not the cause of increased sphingomyelin, but must be oxidized to increase the level of sphingomyelin (Table 1).

In humans, excess oxysterols stimulated the synthesis of sphingomyelin and inhibited sphingomyelin metabolism [5-6]. By using a radiolabeled methyl- ${ }^{3} \mathrm{H}$ choline, the time- and dose-dependent effects of 27hydroxycholesterol on sphingomyelin synthesis into coronary artery cells could be observed. 27Hydroxycholesterol at a level of $0.1 \mu \mathrm{g} / \mathrm{mL}$, which is within the range of its plasma concentration in healthy adults had no obviously stimulating effect on the incorporation of choline label into sphingomyelin from phosphatidylcholine during 15 days of treatment. When the level was increased to $0.5 \mu \mathrm{g} / \mathrm{mL}$, however, it took only 3 days for 27-hydroxycholesterol to increase radioactivity in sphingomyelin. These results indicate that 27-hydroxycholesterol, an oxysterol, only increases transfer of choline from phosphatidylcholine into sphingomyelin when it is present in concentrations higher than those found in healthy adults. This was consistent with the reports that both 27hydroxycholesterol and sphingomyelin increase in atherosclerosis [7].

The sphingomyelin contributed to the occlusion of the veins and arteries of these patients because of the binding of calcium $\left(\mathrm{Ca}^{2+}\right)$ to sphingomyelin. According to Shah and Schulman, [8] the binding of $\mathrm{Ca}^{2+}$ to monolayers of phospholipids such as sphingomyelin happens because of the hydrogenation of

Table 1: Effect of Cholesterol and 25- and 26- Hydroxycholesterol on Cell Growth and Cell Viability of Human Umbilical Artery Smooth Muscle Cells ${ }^{\mathrm{a}}$

\begin{tabular}{|c|c|c|c|}
\hline Mode of Treatment & 1 Day & 3 Day & 5 Day \\
\hline \multicolumn{4}{|l|}{ Number $\left(\times 10^{4}\right)$} \\
\hline $0.5 \%$ Ethanol & $1.9 \pm 0.2$ & $2.1 \pm 0.3$ & $2.3 \pm 0.3$ \\
\hline \multicolumn{4}{|l|}{$\mathrm{CHOL}(\mu \mathrm{g})$} \\
\hline 10 & $1.9 \pm 0.2$ & $1.9 \pm 0.1$ & $2.3 \pm 0.2$ \\
\hline 2.5 & $1.8 \pm 0.2$ & $1.9 \pm 0.2$ & $2.3 \pm 0.2$ \\
\hline 0.5 & $1.9 \pm 0.2$ & $2.2 \pm 0.1$ & $2.4 \pm 0.2$ \\
\hline \multicolumn{4}{|l|}{$25-\mathrm{OHC}(\mu \mathrm{g})$} \\
\hline 10 & $1.4 \pm 0.2^{b}$ & $1.1 \pm 0.1^{c}$ & $0.6 \pm 0.1^{c}$ \\
\hline 2.5 & $1.7 \pm 0.2$ & $1.3 \pm 0.1^{c}$ & $1.0 \pm 0.1^{\mathrm{c}}$ \\
\hline 0.5 & $1.7 \pm 0.2$ & $1.7 \pm 0.1^{b}$ & $1.6 \pm 0.1^{c}$ \\
\hline \multicolumn{4}{|l|}{$26-\mathrm{OHC}(\mu \mathrm{g})$} \\
\hline 10 & $1.5 \pm 0.1$ & $1.3 \pm 0.2^{c}$ & $0.9 \pm 0.1^{c}$ \\
\hline 2.5 & $1.7 \pm 0.2$ & $1.7 \pm 0.2$ & $1.7 \pm 0.1^{b}$ \\
\hline 0.5 & $1.7 \pm 0.1$ & $1.7 \pm 0.2$ & $1.7 \pm 0.1$ \\
\hline \multicolumn{4}{|l|}{ Viability (\%) } \\
\hline $0.5 \%$ Ethanol & $95 \pm 3.2$ & $94 \pm 3.6$ & $93 \pm 4.8$ \\
\hline \multicolumn{4}{|l|}{$\mathrm{CHOL}(\mu \mathrm{g})$} \\
\hline 10 & $99 \pm 2.4$ & $97 \pm 4.6$ & $98 \pm 5.1$ \\
\hline 2.5 & $94 \pm 6.5$ & $99 \pm 3.5$ & $98 \pm 8.9$ \\
\hline 0.5 & $98 \pm 2.3$ & $98 \pm 3.7$ & $94 \pm 6.9$ \\
\hline \multicolumn{4}{|l|}{$25-\mathrm{OHC}(\mu \mathrm{g})$} \\
\hline 10 & $81 \pm 3.6^{b}$ & $61 \pm 8.8^{c}$ & $31 \pm 7.6^{c}$ \\
\hline 2.5 & $91 \pm 5.7$ & $75 \pm 5.7^{b}$ & $44 \pm 7.9^{c}$ \\
\hline 0.5 & $95 \pm 5.1$ & $92 \pm 3.9$ & $88 \pm 8.2$ \\
\hline
\end{tabular}

${ }^{a}$ The data are expressed as cell number $\left(\times 10^{4}\right)$ and cell viability (\%) per culture well. These values are mean \pm SE of duplicate for each independent determination in six cultures. CHOL, cholesterol; 25-OHC, 25-hydroxycholesterol; 26-OHC, 26- hydroxycholesterol.

${ }^{\mathrm{b}} p<0.05$ compared with $0.5 \%$ ethanol group in the same column.

${ }^{c} p<0.01$ compared with $0.5 \%$ ethanol group in the same column. 
Table 2: Phospholipid Composition in Plaque and Non-Plaque Tissue from the Carotid Arteries of the same Coronary Artery Bypass Grafting Surgery Patients

\begin{tabular}{|c|c|c|}
\hline Phospholipid (\%) & non-plaque & plaque \\
\hline Lysophosphatidylcholine & $8.33 \pm 2.6$ & $8.78 \pm 2.3$ \\
\hline Sphingomyelin & $50.93 \pm 2.62^{a}$ & $59.95 \pm 4.35^{\mathrm{a}}$ \\
\hline Phosphatidylcholine & $25.77 \pm 4.37$ & $23.40 \pm 2.34$ \\
\hline Phosphatidylethanolamine \& Phosphatidylserine & $14.03 \pm 4.36$ & $7.28 \pm 1.73$ \\
\hline
\end{tabular}

Results are expressed as mean+S.D. from three patients. Mean values with a common letter are significantly different at a level of $p<0.05$.

sphingomyelin in the presence of salt water. This hydrogenation turns a normally neutral sphingomyelin into an anion with two negative charges. Therefore, $\mathrm{Ca}^{2+}$ is attracted to sphingomyelin and binds to it.

Lipid analysis of the plasma and arterial tissue obtained prior to and during CABG surgery revealed, when compared to controls [9], a higher concentration of oxysterols in the plasma, and a significantly higher concentration of sphingomyelin in arterial tissue. Women under 60 years of age who underwent CABG surgery had $45 \mathrm{ng} / \mathrm{mL}$ more free oxysterols in their plasma than controls. Women over 60 years of age had $33.4 \mathrm{ng} / \mathrm{mL}$ more free oxysterols in their plasma than controls. Likewise, men under 60 years of age who underwent CABG surgery had $50.7 \mathrm{ng} / \mathrm{mL}$ more free oxysterols in their plasma than controls, and men over 60 had $34.6 \mathrm{ng} / \mathrm{mL}$ more free oxysterols in their plasma than controls. Seven oxysterols were found in the plasma. Five of these have also been identified in the liver of rabbits fed oxidized cholesterol [1]. Two were found in over used frying fat and egg yolk powder (27-

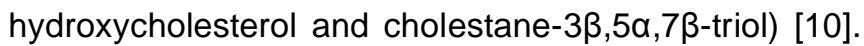
These results suggest that these oxysterols are absorbed from the diet and may originate from commercially fried and processed foods.

Analysis of the concentration of cholesterol, lipid oxidation products, and total antioxidant capacity in the plasma of 2,000 cardiac catheterized patients with 0 , $10-69$, and $70-100 \%$ stenosis of their arteries [11].
The results showed that lipid oxidation products increased with the severity of stenosis. The total antioxidant capacity decreased with the severity of stenosis. The plasma cholesterol concentration, however, was not significantly different between these groups of patients. Therefore, the concentration of oxidation products rather than the concentration of cholesterol in the plasma increased with the severity of coronary heart disease.

The lipid composition and calcium concentration in plaque tissue of the carotid and coronary arteries were analyzed. The total phospholipid concentration in the plaque of the carotid arteries of the CABG surgery patients did not differ from that in the non-plaque area from the same patient (Table 2).

However, the percentages of individual phospholipids were changed. The percentage of sphingomyelin in the plaque was more than $20 \%$ higher than in the non-plaque tissues from carotid arteries. In coronary arteries, an almost $20 \%$ increase of sphingomyelin was also observed in the hard areas that would later form a plaque. In these areas, the calcium concentration also significantly increased to $23.6 \pm 12.1 \mathrm{mg} / \mathrm{g}$ tissue, compared to $5.0 \pm 1.02 \mathrm{mg} / \mathrm{g}$ tissue in the surrounding soft areas (Table 3 ).

The presence of thromboxane, a potent inducer of vasoconstriction and platelet adhesion, in the arteries is partially responsible for the interruption of blood flow,

Table 3: Phospholipid Composition in the Hard and the Surrounding Soft Tissue from the Coronary Arteries of the Same Non-Coronary Artery Bypass Grafting Surgery Patients

\begin{tabular}{|c|c|c|}
\hline Phospholipid (\%) & soft & hard \\
\hline \hline Lysophosphatidylcholine & $6.58 \pm 2.40^{\mathrm{a}}$ & $10.64 \pm 2.26^{\mathrm{a}}$ \\
\hline Sphingomyelin & $38.3 \pm 3.96^{\mathrm{b}}$ & $49.10_{ \pm} 3.38^{\mathrm{b}}$ \\
\hline Phosphatidylcholine & $34.2 \pm 3.78$ & $30.70 \pm 3.57$ \\
\hline Phosphatidylethanolamine \& Phosphatidylserine & $20.4 \pm 5.4^{\mathrm{c}}$ & $9.48 \pm 3.2^{\mathrm{c}}$ \\
\hline
\end{tabular}

Results are expressed as mean \pm S.D. from ten patients. Mean values with a common letter are significantly different at a level of $p<0.05$. 
causing the clogging of the arteries [12]. The components of oxLDL were responsible for platelet sensitization to thrombin and the increase of thromboxane release. More significantly, we found that oxLDL at low concentrations is more potent in enhancing the platelet response to thrombin and to increasing thromboxane release than native LDL [13]. In contrast, prostacyclin is vasoprotective, and keeps blood flowing. It is a dominant prostaglandin produced by endothelial cells and is a potent vasodilator and inhibitor of platelet aggregation and leukocyte adhesion [14].

Smoking cigarettes and consuming trans fatty acids in partially hydrogenated fats in the diet inhibits prostacyclin generation by the coronary arteries [1520]. Cigarette smoke is a major risk factor for atherosclerosis and is associated with coronary, cerebral, and peripheral vascular disease. Cigarette smoke is a mixture of gases and particulate matter. Each puff has been reported to contain $10^{15}$ free radicals in each phase (soluble and particulate) [21].
Both phases contain high concentrations of reactive oxygen species, nitrogen oxide, peroxynitrate, and free radicals of organic compounds which cause two major processes: the oxidation of LDL and the inhibition of prostacyclin synthesis, both dangerous for life [14]. According to Maddox, sudden cardiac death is the largest cause of natural death in the U.S., causing about 325,000 adult deaths in the United States each year [22].

Data from the U.S. Department of Agriculture indicated that from 1912 through 2011, the consumption of polyunsaturated fat has increased from 11.3 pound per capita to 64.5 pounds per capita and saturated fat has decreased from 28 pounds per capita to 13.4 pounds per capita in the same period (Table 4). Out of the 18 billion pounds of soybean oil produced per year in the USA, 9 billion is used in the diet. If the oil is completely hydrogenated and diluted with the proper amount of corn oil it would serve as an addition to the saturated fat that is needed in the diet. The main

Table 4: Fats and Vegetable Oils Consumption in US Since 1912 Per Capita (in Pounds)

\begin{tabular}{|c|c|c|c|c|c|c|c|c|}
\hline \multirow{2}{*}{$\begin{array}{l}\text { Years } \\
\text { Items }\end{array}$} & \multicolumn{2}{|c|}{1912} & \multicolumn{2}{|c|}{1950} & \multicolumn{2}{|c|}{1999} & \multicolumn{2}{|c|}{2011} \\
\hline & Total $^{*}$ & Per cap & Total $^{*}$ & Per cap & Total $^{*}$ & Per cap. & Total $^{*}$ & Per cap \\
\hline Corn oil & 53.0 & 0.6 & 223.0 & 1.47 & 1416.9 & 5.2 & 1620.0 & 5.2 \\
\hline Cottonseed oil & 950.0 & 10.0 & 1445.0 & 9.51 & 832.8 & 3.1 & 620.0 & 2.0 \\
\hline Olive oil & 43.0 & 0.5 & 76.0 & 0.50 & 329.8 & 1.2 & 650.1 & 2.1 \\
\hline Palm oil & 0.0 & 0.0 & 26.0 & 0.17 & 416 & 1.5 & 2525.2 & 8.1 \\
\hline Palm kernel oil & 0.0 & 0.0 & 26.0 & 0.17 & 233.2 & 0.9 & 778.0 & 2.5 \\
\hline Peanut oil & 8.0 & 0.1 & 103.0 & 0.68 & 1524.7 & 5.6 & 202.7 & 0.6 \\
\hline Canola oil & 0.0 & 0.0 & 0.0 & 0.00 & 111.2 & 0.4 & 4249.0 & 13.6 \\
\hline Safflower oil & 0.0 & 0.0 & 5.1 & 0.03 & 15.8 & 0.1 & 60.9 & 0.2 \\
\hline Sesame oil & 0.0 & 0.0 & 5.0 & 0.03 & 15.8 & 0.1 & 27.2 & 0.1 \\
\hline Soybean oil & 16.0 & 0.2 & 1446.0 & 9.51 & 8029.6 & 29.4 & 9000.0 & 28.8 \\
\hline Sunflower oil & 0.0 & 0.0 & 0.5 & 0.00 & 393.7 & 1.4 & 395 & 1.3 \\
\hline Total unsaturated oils & 1070.0 & 11.3 & 3355.6 & 22.1 & 13319.5 & 48.8 & 20128.1 & 64.5 \\
\hline Lard & 1069.0 & 11.2 & 1891.0 & 12.60 & 202.0 & 0.7 & 480.0 & 1.5 \\
\hline Butter & 1579.0 & 16.6 & 1648.0 & 10.70 & 1307.0 & 4.8 & 1510.0 & 4.8 \\
\hline Tallow & 22.0 & 0.2 & 69.0 & 0.45 & 996.0 & 3.6 & 1050.0 & 3.4 \\
\hline Coconut & 0.0 & 0.0 & 69.0 & 0.45 & 927.0 & 3.4 & 1155.1 & 3.7 \\
\hline Total saturated fats & 2670.0 & 28.0 & 3677.0 & 24.2 & 3432.0 & 12.6 & 4195.1 & 13.4 \\
\hline $\begin{array}{l}\text { US Population in } \\
\text { millions }\end{array}$ & \multicolumn{2}{|c|}{95} & \multicolumn{2}{|c|}{152} & \multicolumn{2}{|c|}{273} & \multicolumn{2}{|c|}{312} \\
\hline
\end{tabular}

(*) Totals in millions of pounds.

Courtesy Mark Ash, of U.S. Department of Agriculture.

http://factfinder2.census.gov/faces/tableservices/sf/pages/productview.xhtml?pid=ACS 11 1YR DP05\&prodType=table http://www.npg.org/facts/us_historical_pops.htm 
generator of atherosclerosis and sudden death are oxLDL and oxysterols in excess.

\section{ACKNOWLEDGEMENTS}

I wish to thank Dr. Chris Masterjohn, Ph.D. for his helpful insight and editing of the text. I like to also thank Dr. MM. Mahfouz Ph.D., Dr. Qi Zhou MD., Drs. L. Cook and T. Connelly for the tissue and Dr. B. Handler for the blood, cardiologist at Carle Hospital, Urbana, Illinois, and my assistant, Leatrice Potter. This work was supported by funding from The Weston A. Price Foundation, the Verna L. and John R. Hildebrand Foundation, Burnsides Oils Revenue Funds and $\$ 175,000$ of my own retirement funds.

\section{REFERENCES}

[1] Staprans I, Xian-Mang P, Rapp JH, Feingold KR. Oxidized Cholesterol in the Diet Accelerates the Development of Aortic Atherosclerosis in Cholesterol-Fed Rabbits. Arteriosclerosis, Thrombosis, and Vascular Biology 1998; 18: 977-83. http://dx.doi.org/10.1161/01.ATV.18.6.977

[2] De Bakey ME, Diethrich EB, Garrett HE, McCutchen JJ. Surgical treatment of cerebrovascular disease. Postgrad Med 1967; 42: 218-30.

[3] Kummerow FA, Przybylski R, Wasowicz E. Changes in arterial membrane lipid composition may precede growth factor influence in the pathogenesis of atherosclerosis. Artery 1994; 21: 63-75.

[4] Zhou Q, Smith T, Kummerow FA. Cytotoxicity of Oxysterols on Cultured Smooth Muscle Cells from Human Umbilical Arteries. Soc Exper Biol Med 1993; 202: 75-80. http://dx.doi.org/10.3181/00379727-202-43514

[5] Zhou Q, Kummerow FA. Effect of 27-hydroxycholesterol on cellular sphingomyelin synthesis and $\mathrm{Ca}++$ content in cultured smooth muscle cells. Biomed Environ Sci 1997; 10: 369-76.

[6] Zhou Q, Kummerow FA. Alterations of $\mathrm{Ca}^{++}$Uptake and Lipid Content in Cultured Human Arterial Smooth Muscle Cells Treated with 26-Hydrocholesterol. Artery 1994; 21(4): 18292.

[7] Javitt NB. 26-Hydroxycholesterol: synthesis, metabolism, and biologic activities. J Lipid Res 1990; 31: 1527-33.

[8] Shah DO, Schulman JH. Interaction of calcium ions with lecithin and sphingomyelin monolayers. Lipids 1967; 2: 2127. http://dx.doi.org/10.1007/BF02531995

[9] Kummerow FA, Cook LS, Wasowicz E, Jelen H. Changes in the phospholipid composition of the arterial cell can result in severe atherosclerotic lesions. J Nutr Biochem 2001; 12: 602-607.

http://dx.doi.org/10.1016/S0955-2863(01)00181-4
[10] Smith LL. Cholesterol autoxidation. New York: Plenum 1981. http://dx.doi.org/10.1007/978-1-4757-9691-9

[11] Kummerow FA, Olinescu RM, Fleischer L, Handler B, Shinkareva SV. The relationship of oxidized lipids to coronary artery stenosis. Atherosclerosis 2000; 149: 181-90. http://dx.doi.org/10.1016/S0021-9150(99)00378-0

[12] Mahfouz MM, Kummerow FA. Oxysterols and TBARS are among the LDL oxidation products which enhance thromboxane A2 synthesis by platelets. Prostaglandins Other Lipid Mediat 1998; 56: 197-17. http://dx.doi.org/10.1016/S0090-6980(98)00056-2

[13] Mahfouz MM, Kummerow FA. Oxidized low-density lipoprotein (LDL) enhances thromboxane $A(2)$ synthesis by platelets, but lysolecithin as a product of LDL oxidation has an inhibitory effect. Prostaglandins Other Lipid Mediat 2000; 62: 183-200.

http://dx.doi.org/10.1016/S0090-6980(00)00078-2

[14] Mahfouz MM, Zhou Q, Kummerow FA. Inhibition of prostacyclin release by cigarette smoke extract in endothelial cells is not related to enhanced superoxide generation and NADPH-oxidase activation. J Environ Pathol Toxicol Oncol 2006; 25: 585-95.

http://dx.doi.org/10.1615/JEnvironPatholToxicolOncol.v25.i3. $\underline{30}$

[15] Kummerow FA, Mahfouz MM, Zhou Q. Trans fatty acids in partially hydrogenated soybean oil inhibit prostacyclin release by endothelial cells in presence of high level of linoleic acid. Prostaglandins Other Lipid Mediat 2007; 84: 138-53.

http://dx.doi.org/10.1016/j.prostaglandins.2007.07.001

[16] Kummerow FA. The negative effects of hydrogenated trans fats and what to do about them. Atherosclerosis 2009; 205 : 458-65. http://dx.doi.org/10.1016/j.atherosclerosis.2009.03.009

[17] Vane JR, Bakhle YS, Botting RM. Cyclooxygenase 1 and 2. Annu Rev Pharmacol Toxicol 1998; 38: 98-20. http://dx.doi.org/10.1146/annurev.pharmtox.38.1.97

[18] Vane JR, Mitchell JA, Appleton I. Inducible isoforms of cyclooxygenase and nitric-oxide synthase in inflammation. Proc Natl Acad Sci USA 1994; 91: 2046-50. http://dx.doi.org/10.1073/pnas.91.6.2046

[19] Kummerow FA. Improving hydrogenated fat for the world population. Prevention Control 2005; 1: 157-64. http://dx.doi.org/10.1016/j.precon.2005.05.003

[20] Vesper HW, Kuiper HC, Mirel, LB, Johnson CL, Pirkle JL. Research Letter: Levels of Plasma trans-Fatty Acids in NonHispanic White Adults in the United States in 2000 and 2009. JAMA 2012; 307(6): 562-63. http://dx.doi.org/10.1001/jama.2012.112

[21] Pryor WA. The role of free radical reactions in biological systems. New York: Academic Press 1977.

[22] Maddox T. Heart disease and sudden cardiac death Retrieved from http://www/webmd.com/heart-disease/guide/ sudden-cardiac-death; Accessed 1 May 2012.

\section{DOl: http://dx.doi.org/10.6000/1929-5634.2013.02.02.7}

(c) 2013 Fred A. Kummerow; Licensee Lifescience Global.

This is an open access article licensed under the terms of the Creative Commons Attribution Non-Commercial License (http://creativecommons.org/licenses/by-nc/3.0/) which permits unrestricted, non-commercial use, distribution and reproduction in any medium, provided the work is properly cited. 